https://helda.helsinki.fi

\title{
Post errorem
}

\section{Chesterman, Andrew}

2019-08-03

Chesterman , A 2019 , ' Post errorem ' , Perspectives : Studies in Translatology , vol. 27 , no. 5 , pp. 664-674 . https://doi.org/10.1080/0907676X.2018.1450884

http://hdl.handle.net/10138/325630

https://doi.org/10.1080/0907676X.2018.1450884

unspecified

acceptedVersion

Downloaded from Helda, University of Helsinki institutional repository.

This is an electronic reprint of the original article.

This reprint may differ from the original in pagination and typographic detail.

Please cite the original version. 


\title{
Post errorem
}

[2018. Perspectives. Studies in Translation Theory and Practice 27, 5, 664674.]

\author{
Andrew Chesterman \\ Department of Languages, University of Helsinki
}

\begin{abstract}
Six cases or case types are briefly presented, illustrating a number of loose ends in translation ethics. These cases are related to reactions by different agents or voices to a clear error, and the ethical implications of these reactions. Case 1 is invented; it raises questions of accountability. Case 2 concerns reactions to errors in the source text, and official guidelines in this respect. Case 3 problematizes a literary translator's refusal to correct certain errors. Case 4 discusses the descriptivist scholar's problem of how to deal with clear errors. Case 5 is about a creative reaction to a serious problem in court interpreting. And case 6 analyses the ethical dilemma of trying to change traditional interpretations of passages in a sacred text, for good utilitarian reasons. Loose ends include: the need to revise codes of ethics; the clash between contractual and utilitarian ethics; clashes between voices; and the relation between personal and professional ethics (e.g. in interventionist translation).
\end{abstract}

Keywords: ethics; errors; reactions; voices; intervention

\section{Introduction}

The Latin phrase of my title has a theological origin, having to do with the consequences of sin, including forgiveness. It can be found, for example, in the writings of St. Augustine and Bede. It thus has serious ethical connotations. Here, I take the phrase post errorem as an umbrella term for several kinds of ethical problems that can 
arise as a consequence of something in the source or target text that is clearly wrong. By "clearly wrong" I refer here primarily to the misrepresentation of facts or content. I also assume that something can be said to be clearly wrong if a "correct" alternative is easily available. In this sense, an error stands in a binary relation with a correct alternative. Such an error is not merely a question of taste, which can be debated (cf. Pym 1992). We are not dealing here with target-language errors as such. The cases illustrate different kinds of misrepresentation, and the consequences of this.

What interests me is the ethics of the reactions that can be observed, by different agents (or, if you like, expressed by different voices). What happens after an error is observed? And observed by whom? And what should happen, ethically speaking?

In the default case, of course, the answer is easy: if the error is observed by the translator or reviser, it should be corrected. If you show the translator his/her text, and point to a particular solution with raised eyebrows, and the translator says something like "Oops, that should of course be ...", there is no ethical problem.

\section{Case 1}

First, an invented case to set the scene: a serious error is observed by the client, too late for it to be corrected. (I am indebted to Ulf Norberg for this example ${ }^{1}$.) A cartoon shows a massive meltdown of some huge nuclear plant or the like, a total disaster scene: the manager is on the phone: "Can I speak to the translator, please?" In this imagined scenario, if indeed the translator has made a critical error, e.g. in mistransferring a number from source to target, one only hopes that he/she has a good insurance policy. Is the manager behaving ethically? Yes, if the idea is to prevent this fatal error from

\footnotetext{
${ }^{1}$ I have learned later, from Ulf, that the cartoon is probably by Robert Nyberg.
} 
occurring again. On the other hand, we are all careless sometimes. Did the translator act unethically? Was the translator qualified and competent? What about any other agents involved? Who selected the translator? Was the task subcontracted? Were the working conditions and the deadline ethically acceptable? Was the translation checked, and even rechecked, by someone different, and by qualified revisers each time? If the translator works for an agency, did the agency subscribe to the latest international quality standard? And were the working procedures followed really in accordance with this standard? Who was the project manager? Who is to blame? Where does the translator's accountability end? What is the extent of his/her liability? In this case, of course we don't know, but these are relevant questions.

\section{Case 2}

This is a case type rather than an individual example. The translator notices a factual error in the source text. Should it be corrected? According to a survey of 17 codes of ethics surveyed by McDonough Dolmaya (2011a), advice on this varies. Most of the codes she looked at mentioned the value of accuracy or fidelity, but there was little agreement on how this should be defined. Many codes give no guidance at all on what translators should do. Some stipulate that translators must convey everything, including untrue statements; others say one should inform clients of significant errors. The AUSIT (Australian Institute of Interpreters and Translators) Code of ethics cited by Dolmaya in 2011 said:

If patent untruths are uttered or written, interpreters and translators shall convey these accurately as presented. Interpreters and translators shall not alter, make additions to, or omit anything from their assigned work. (AUSIT Code of ethics, Articles 5 (a) iii-iv) 
The current (2012) version has been improved (as a result, perhaps, of Dolmaya's article?) to:

Interpreters and translators use their best professional judgement in remaining faithful at all times to the meaning of texts and messages.

Explanation: Accuracy for the purpose of this Code means optimal and complete message transfer into the target language preserving the content and intent of the source message or text without omission or distortion.

(Online at AUSIT Code of Ethics and Code of Conduct)

Compare Peter Newmark's well-known assertion: “Translation is concerned with moral and with factual truth" (Newmark 1991, p. 1). If you agree with Newmark, you would be justified in thinking that some of the current codes of translator ethics are less than satisfactory in this respect. At the very least, the guidance they offer should be made sensitive to text type and to skopos. Medical translators or hospital interpreters cannot simply transfer obviously inaccurate dose amounts from source to target without querying and checking. Translators and interpreters are evidently aware of this problem, where there is either no guidance available or the advice given goes against common sense in a particular case. The question of what translators should do about source text errors is one of the issues that came up in McDonough Dolmaya's data from an online discussion forum (the Ethics and Professionalism forum of TranslatorsCafe.com) where translators and interpreters raise ethical problems they have faced in their work.

\section{Case 3}

A recent project in Finland, organized by the major publisher WSOY, has commissioned and now published retranslations of all Shakespeare's plays, using several translators, some of whom are well-known literary translators and others are 
less experienced. The translations were checked by editors and a scholarly consultant before publication. A Finnish translation scholar, Nestori Siponkoski, undertook a $\mathrm{PhD}$ that examined the comments made by the editors and the consultant, and the reactions of the translators to these comments (Siponkoski 2014). One of his findings was that the more experienced translators were less likely to accept suggested corrections than more junior colleagues. They had more confidence that their solutions were correct. This is of course understandable, but also potentially worrying. Even an established translator, with high cultural status, can err, and if this occurs he/she should, ethically speaking, surely be humble enough to admit it and accept a correction. Most of the comments Siponkoski analysed have to do with style and would not be classified as clear misunderstandings. When these latter do occur, and are commented on, they are apparently corrected (the $\mathrm{PhD}$ does not show all the data).

However - and this is the point I want to draw attention to - sometimes errors do slip through the net of revision and appear in the published version. Well, stuff happens. But now the publishers are planning e-book versions and reprints, so one would imagine that additional corrections could be made. Indeed, one of the editors said she would welcome comments about misprints and errors etc. that could be corrected. (Here I am drawing on some personal communications from people I will not identify.) What happens when attention is drawn to things that should be corrected for the new edition? Here are a couple of examples from one play, Macbeth, translated by a very experienced translator.

At the beginning of Act I, Scene 2, King Duncan and others arrive on the stage, "meeting a bleeding Sergeant", as the stage directions put it. The King asks:

ST: What bloody man is that? He can report, As seemeth by his plight, of the revolt 
The newest state.

Malcom then tells the King that this is the Sergeant, bids the man welcome, and asks him to tell his news ("Hail, brave friend! / Say to the king the knowledge of the broil / As thou didst leave it"). And the Sergeant tells his story, until he says "But I am faint, my gashes cry for help," after which King Duncan expresses his appreciation of the report, and says "Go, get him surgeons." And the scene ends thus: [Exit Sergeant, attended].

But the Finnish translation of the King's first sentence is:

TT: Kuka tuossa makaa verissään?

(who there lies in-his-blood)

Now, if the unfortunate captain is lying on the ground when the King sees him, it is odd that the King should ask him all about the recent battle before getting him any help. Duncan is not that kind of unfeeling person, as represented in Shakespeare's text. It is also odd that Malcolm should say "Hail" to a man lying on the ground. Moreover, if the man is already on the ground, he is not being "met". In the original, one naturally imagines the man entering from one side of the stage, no doubt staggering to indicate that he has been wounded, while the King's company enter from the other, and there is a "meeting". The semantic difference between the English and the Finnish is not enormous, but it is undeniable, and easily correctable.

In Act IV, Scene 3 there is a discussion between Macduff and Malcolm about the miraculous curative abilities of the English king. There is reference to a disease called "the evil", which is otherwise known as the king's evil, or scrofula, causing swollen glands in the neck. The text even mentions the king's practice of hanging “a golden stamp” around sufferers' necks. In Finnish, scrofula is risatauti 
(literally 'tonsils disease'), but the new translation has silmätauti ('eye disease').

The same translator's earlier translation (from 1983) has a literal translation "kuninkaan tauti” ('the king's disease'). The classic Cajander translation (1885) has "riisi", i.e. riisitauti ('rickets', which is a bone disease). None of these are pragmatically as serious as the imagined errors (such as mistransferred numbers) in case 1 , but they are not semantically accurate.

There were a few other easily correctable things too, a list of which was sent to the editor. What struck me was the reaction of two agents when their attention was drawn to these semantic errors. The editor was grateful for the observations, said she agreed that they were errors, and that they should be corrected. But the translator refused to change anything, on the grounds that the text was "a whole", and therefore individual details could not be tampered with at some later stage. I found this argument astonishing and thoroughly unethical, and the translator's behaviour absolutely unprofessional. The translator appeared to consider his literary translation as a fixed text, as some sacred texts are regarded by some believers, and therefore untouchable. Since the translator did not give the editor permission to make any changes, nothing could be done - a most unsatisfactory situation.

The translator's original erroneous solutions (of the kind illustrated above) in this case go against the fidelity requirements mentioned in most codes of ethics. The Translators Charter has a clause (no. 30) giving translator unions and associations the competence to act as arbiters in cases of dispute: perhaps in this case the client could have referred the issue to the Finnish Association of Translators and Interpreters. But suppose the translator in question is not a member? Would he be bound to accept the Association's decision? In an earlier 
article (2001) I proposed a Hieronymic Oath which included the commitment to agree to arbitration in cases of dispute. In the case we are looking at, no formal arbitration was provided, however. Perhaps there should be a more explicit clause in such codes, to the effect that "a translator shall agree to make justified changes when requested by the client or a competent arbiter, for example for a new edition of the text". True, this would entail agreement on the interpretation of "justified"; but such a clause would at least specify the requirement of some discussion.

\section{Case 4}

This is another case type, and is very different, having to do with the post errorem reactions of a scholar or critic. The problem at issue here may seem more academic than ethical, but let us see.

Since the advent of Descriptive Translation Studies, descriptive scholars have hesitated to pronounce that a particular translation solution is "wrong", because that would sound prescriptive. Malmjkær (2004) proposes a solution to this dilemma in a descriptive analysis of a number of what prescriptivists would undoubtedly call errors, in an early English translation of some stories by Hans Christian Andersen. The Danish word Strudsen 'the ostrich' is translated the simoom (a dry desert wind), rolig 'still' becomes funnily, Sommerfuglene 'the butterflies' becomes the summer birds, and so on. Malmkjær's solution is to focus on the potential causes of these errors. She comes up with some plausible proposals such as the translator being misled by false friends or spelling similarities, or misunderstanding the syntax, but some errors appear to have no imaginable motivation at all - a very strong reason to categorize them as errors in the first place. Translatorial manipulations such as the avoidance of blasphemy or sexual 
associations are no doubt motivated by ideological concerns which might lead to censorship. Malmkjær's point is that there are ways of distinguishing between translator choice (implying the translator's intention, with which the scholar may not necessarily agree) and translator error (for which reasons such as formal interference may be proposed in some cases, although not necessarily all). We can also speculate that if the translator had been aware of the errors discussed by Malmkjær, she would surely have corrected them.

Literary critics are often happy to combine descriptive and prescriptive attitudes. Hewson (2011), for instance, developed a detailed critical model which combines a descriptive hermeneutic analysis of the relation between source and target texts and a quality assessment based on the degree to which the translator's choices are justified. His main quality criterion was the effect that a given choice will have on the reader's potential interpretation, i.e. whether this will match that intended by the original author. In other words, Hewson aimed to assess potential translation effects - based on the effects that given translation choices have on himself. Of course, he might not be a typical reader. But by bringing in a consideration of effects, Hewson was implicitly offering a solution to the descriptivist's dilemma when confronted with evident errors: one can describe effects - that is, empirically observed actual ones - and indeed make predictions on the basis of such observations. In this way a so-called prescriptive viewpoint can be included within a descriptive approach. (For a fuller statement of this argument, see Chesterman 1999.)

While Malmkjær's approach to errors focused on their causes, Hewson thus considered both justifications and potential effects. Consideration of effects suggests a utilitarian kind of ethics: does that make it more ethical? Both Malmkjær 
and Hewson were concerned with either actual or potential misinterpretations that could and should have been avoided. Here the yardstick is the intention - the intended effect - of the original author. But one cause of what seems to be an error might be the translator's intention (as Case 6 will illustrate). In cases of clash between the intentions of different stake-holding voices - the original author, the translator, the scholar, other readers - what should ethically happen, under what conditions? Whose voice should ethically prevail, and why? Another question also arises: how should we analyse, from an ethical point of view, the relation between misinterpretations and undesirable interpretations? This question also implies another: undesirable to whom? These questions do not appear to have easy answers.

\section{Case 5}

This case illustrates one constructive approach to these questions, and expands my notion of "error" to include the kind of example in which the target representation of the source message is simply not understood by the intended recipient. The case was analysed in the doctoral thesis of a professional interpreter, Julia Lambertini Andreotti (2016). Some of her practical work is in court interpreting in California. Over the years, she has noticed that many of her Spanish-speaking clients (i.e. those who are accused, or interrogated as witnesses) do not understand much of the formal legal Spanish that the interpreter uses. So the "error" in this case has the effect of non-understanding. These are undeniably undesirable consequences undesirable to all parties. (The thesis discusses some of the potential causes of this comprehension problem, including educational and cultural factors.)

The interpreters interviewed in this study (and Andreotti herself) would like to make the necessary simplifications so that the clients would be able to 
understand what is said to them, but the Californian code of ethics for court interpreters forbids this.

The Californian Judicial Council states as follows (from Andreotti 2016: 48):
When rendering the source-language message into the target language, you must never alter the register, or level of language, to make it easier to understand or more socially acceptable. For instance, if the attorney asks, "What did you observe the subject to do subsequently?" you should not say in the target language, "What did you see him do next?" if more formal synonyms exist. You should not try to bring the question down to the witness's level. You also should not intervene and say that you do not think the question is understandable to the witness. If the witness does not understand the question, it is his responsibility, or that of the attorney who has called him to the stand, to say so. It is not the interpreter's job to evaluate and give an opinion on the witness's ability to understand.

The code specifies elsewhere (p. 3) that the aim of the interpreting is to place English and non-English speakers on an equal footing, facilitating comprehension and communication. But it also states that interpreters must convey both the content and the form of the source message, and (see the quotation above) they must not change the high legal register of the proceedings. So we have a dilemma: the aims of the system are not realized, because clients do not understand the high register and the interpreters cannot change the register for them. The problem is made still more acute by the fact that the clients often cannot even articulate their own lack of comprehension.

How should a scholar react? Well, one could publicize the problem, for instance in a $\mathrm{PhD}$, and then try to change the law: both scholarly and social action. Andreotti first set out to test her impression that most of her clients did not understand much: this impression was indeed verified. She then prepared a 
simplified version, and tested again: surprise surprise, much better comprehension (but still not as good as that of a control group of English speakers: possible reasons are discussed). Andreotti interestingly discovered that many court interpreters, when the risk of exposure is low, voluntarily go against the official code and use a number of obvious simplification and clarification strategies when possible. Sometimes they even get the attorney's permission to do this.

Andreotti concluded with the hope that more attention should be given, in training and practice, to the "the significance of the set of norms that seems to guide [interpreters] in their decisions when nobody is looking" (2016: 262). In other words, the official code should be influenced by what seems to be happening in thoughtful professional practice. This would mean that the rule about maintaining a high register should be relaxed or scrapped. An interpreter participant in one of her focus groups spoke of "a tendency to want to help people, and both sides, to be understood" (ibid.). This tendency might be allowed to overrule the clause about preserving a high register.

The above situation raises the issue of the role of personal ethics, and to the difficult relation between personal and professional ethics. This is precisely the topic of a book by Inghilleri (2012), who argues in various ways that professional interpreters need to be allowed to give more influence to their own personal ethics, and to intervene as experts when they feel that communication is not succeeding. The individual arguments in this book may not all be equally convincing, but I absolutely agree that the relation between personal and professional ethics needs much more attention than it has hitherto received. Court interpreting is surely one of the contexts in which the utilitarian goal of facilitating understanding (or, perhaps more realistically, the inverse utilitarian goal of reducing mis- and non- 
understanding as much as possible) should take precedence over the preservation of formal style and register.

\section{Case 6}

My last case also concerns scholarly reactions. It addresses an aspect of interventionist translation (cf. e.g. Munday 2007, Ayyad and Pym 2012). It might also be called an example of "prophylactic translation" (O'Sullivan 2011), which "seeks to forestall the potential harm done by a potentially threatening text by presenting it in a form which will neutralize any negative consequences" (ibid.: 200). The case concerns a sacred text, the Koran. It is well known that, officially, the Koran is never "translated", despite the abundance of various versions in different languages; but this is not relevant to my point. The context here is the very reasonable concern about the spread of fundamentalist interpretations of the text, which appear to be one of the causes of current terrorism: certain bits are taken from the Koran and cited as ideological justification for awful actions. Many moderate Muslims rightly condemn such acts, and some seek to provide alternative interpretations of key passages, interpretations that would be more compatible with, for instance, the values expressed in the Universal Declaration of Human Rights. Sometimes, such moderate interpretations may indeed be justified by the text, but it seems not always. The moderates sometimes have to claim that the text means something that it plainly does not mean. In so doing, they give a false representation of the intention of the original, and ethical doubts can be raised.

This kind of case came to my attention during a paper read at the 2016 European Society for Translation Studies conference in Aarhus (Jaber 2016). My point is this: when is a re-interpretation actually a misrepresentation, or even a lie? When do good utilitarian ends justify truth-denying means? We are not dealing 
with semantic nuances here, but something deeper. If the text explicitly says $\mathrm{X}$, is it ethical to say that it really means Y? I was surprised by the presenter's apparent willingness to sometimes radically change the overt meaning of the source text and thus, so it seemed to me, misrepresent it, and I made a comment to this effect at the end. After the presentation, one person came up to me to express her agreement with my spoken reaction, but another colleague clearly supported the presenter, so we seem to have a real ethical clash here.

An example of this kind of radical re-interpretation strategy (not from the Aarhus paper) is the suggestion that the Arabic word daraba, which literally means 'beat, scourge', in the Koranic verse 4.34 really means 'to cite, i.e. report to the authorities'. (See e.g. www.misconceptions-about-islam.com/wife-beatingquran.htm.) The Penguin Classics translation of this verse is as follows (Koran 1966: 360-1):

\footnotetext{
Men have authority over women because Allah has made the one superior to the other, and because they spend their wealth to maintain them. Good women are obedient. They guard their unseen parts because Allah has guarded them. As for those from whom you fear disobedience, admonish them and send them to beds apart and beat [daraba] them. Then if they obey you, take no further action against them. Allah is high, supreme.
}

This literally correct sense has traditionally been used (together with other sources) as a justification for wife-beating. An ethically defensible alternative for a scholar would be to say that yes, the original text does say this, but nowadays we can disregard its literal reading because times and contexts have changed and values have evolved; so let us add explanatory footnotes, contextualization information, commentary, and so on, for instance using a thick translation (see e.g. AlTarawneh, 2016). For some believers, of course, it would be dangerously heretical 
to pick and choose interpretations that would be appropriate to a modern context. For many, it is "a whole", to be taken as a whole - recall the Shakespeare translator's attitude to his translation, in Case 3.

But compare the Christian Bible, for instance. Many modern scholars would agree that the Old Testament's Hebrew word alma 'young woman' was erroneously translated as parthenos 'virgin' in Greek. And most (but admittedly not all) believers accept that not every verse in this sacred text is relevant to today's world, and so some bits are simply given no attention. This is not the same as trying to interpret them differently, as their original meaning is not in dispute: what is in dispute is their current relevance. In other words, the text is not universally considered to be untouchable, but as a text that can be treated critically. Recall for example the instructions about permitted food etc. in the Old Testament. I assume that few non-vegetarian Christians nowadays follow the instructions to avoid pork, and even fewer would insist that hair and beards must be cut according to the style specified in Leviticus 19:27; fewer still would abstain from wearing clothes made of both linen and wool because of the instruction given in Deuteronomy 22:11.

From an ethical point of view, criticizing the modern relevance of a text fragment is, I suggest, better than denying its original meaning altogether: this latter strategy is surely a form of lying, and goes against an ethics of faithful representation. What is needed is a critical attitude. But the wider problem remains: under what conditions should judgements based on utilitarian ethics take precedence over contractual demands such as fidelity and the value of truth? In the Koran case mentioned, utilitarian ethics have sacrificed the requirements of contractual ethics. 
It seems to me to make a significant difference if the re-reinterpreting is done openly, not hidden. As Berman put it (1995: 93), the translator has the right to do anything he likes, as long as he does it openly ("le traducteur a tous les droits des lors qu'il joue franc jeu"). Recall The Woman's Bible, for instance: an overt attempt to re-interpret a whole sacred book, by means of a detailed critical commentary (see https://archive.org/stream/thewomansbible09880gut/wbibl10.txt). Or, changing the genre, consider an example I have reported on elsewhere (Chesterman, 2009), where a literary translator into German deliberately alters the birth date (April 20) of a fictional hero in order to avoid an unintended Neo-Nazi interpretation. (The day happens to be the original author's birthday too, not just Hitler's.) As a followup to this decision, the translator then explains in a published article what he has done, and why. I find this procedure entirely ethical. But if a translator's radical semantic change is first concealed, then discovered by someone else, what happens to trust?

\section{To conclude: loose ends?}

First, many national (and international) codes of ethics are in need of revision. There should be a clearer definition of the accountability of the various agents involved in a given project. And codes need to be more sensitive to text type, and to the situational context. Attention needs to be paid to cases where existing codes are at odds with good practice. Revised codes might also mean reconsidering the issue of trust. When might an overemphasis on fidelity actually lead to a loss of trust in the profession? When should court interpreters have a right, indeed a duty, to intervene, in order not only to facilitate communication but also to establish trust? 
Does a translator lose trust when it becomes known that he/she has refused the opportunity to correct an obvious error?

Then there is the issue of contractual vs utilitarian ethics. This partly overlaps with the translator's problem of balancing the translator's concern with the text against the requirements of his/her relation with the extratextual world, and partly with competing values: truth, trust, and loyalty (to whom?). In cases of clash, when should one or the other take priority? And who decides? The default position may be that utilitarian considerations take priority, as otherwise we risk sliding into the excuse that "I was only following orders, doing my duty". But I suggest there are exceptions to this, such as case 6 above, where alternative strategies can be prioritized. The key problem is deciding when good ends justify bad means. And what should happen when there is a clash between voices? When does a translator have the duty to bow to an editor's request for a correction? Or: does a translator (under what circumstances?) have a right to refuse to make a correction? Revised codes could go further in specifying such duties, taking account of all agents involved. These days, the number of stake-holding agents is multiplying fast: what about the ethical codes for crowd-sourced translators? Such translators are probably not professionals, and may risk being exploited, but what rights might they have? (See McDonough Dolmaya 2011b.)

Perhaps the most important of the possible "loose ends" I have alluded to here has to do with the relation between personal and professional ethics. This is relevant to all interventionist translation and ideological adaptations of all kinds. When should priority be given to what ethical values? Can guidelines be specified? Perhaps we should pay more attention to the translator's telos (personal, e.g. ideological, motivation; see Chesterman and Baker 2008) as well as the 
translation's skopos. Are translators professionally responsible for working towards a fairer world, or just personally responsible? Or both? Is the promotion of understanding the highest value of a professional translator ethics? And also the limit of professional responsibility?

Maybe some progress could be made towards resolving some of these questions by bringing into our ethical codes some aspects of virtue ethics (see MacIntyre 1981; Chesterman 2001), such as the striving for excellence - even when this means breaking code guidelines and fidelity norms.

\section{References}

Al-Tarawneh, A. (2016). Re-examining Islamic evaluative concepts in English translations of the Quran: Friendship, justice and retaliation. In P. Blumczynski \& J. Gillespie (Eds.), Translating values: Evaluative concepts in translation (pp. 101-122). London: Palgrave Macmillan.

Andreotti, J. L. (2016). Comprehension of Legal Discourse in Interpreter-Mediated Judicial Proceedings. $\mathrm{PhD}$ thesis, Universitat Rovira I Virgili, Tarragona. Available at: http://www.tdx.cat/handle/10803/397782. (Last accessed 31.12.2017)

Ayyad, A., \& Pym, A. (2012). Translator intervention in Middle-East peace initiatives. Detours in the roadmap? In B. Adab, P. A. Schmitt \& G. Shreve (Eds.), Discourses of Translation. Festschrift in Honour of Christina Schäffner (pp. 8399). Frankfurt am Main: Peter Lang.

Berman, A. (1995). Pour une critique des traductions: John Donne. Paris: Gallimard.

Chesterman, A. (1999). The empirical status of prescriptivism. Folia Translatologica, 6, 9-19. 
Chesterman, A. (2001). Proposal for a Hieronymic Oath. The Translator, 7(2), 139154.

Chesterman, A. (2009). An ethical decision. In R. Dimitriu \& M. Shlesinger (Eds.), Translators and their readers. In homage to Eugene Nida (pp. 347-354). Brussels: Éditions du Hazard.

Chesterman, A., and Baker, M. (2008). Ethics of Renarration. (Interview with Mona Baker.) Cultus 1(1), 10-33.

Hewson, L. (2011). An Approach to Translation Criticism: Emma and Madame Bovary in Translation. Amsterdam: Benjamins.

Inghilleri, M. (2012). Interpreting Justice. Ethics, Politics and Language. New York: Routledge

Jaber, Z. (2016). Translating for Muslim Immigrants: Promoting Integration, Combating Terrorism. Paper read at the $8^{\text {th }}$ EST Congress in Aarhus, 15-17 September, 2016. Abstract available via bcom.au.dk/research/conferencesandlectures/estcongress-2016/

Koran, The. (1966). Translated by N. J. Dawood. Harmondsworth: Penguin Books.

MacIntyre, A. (1981). After Virtue. A Study in Moral Theory. Notre Dame, Indiana: University of Notre Dame Press.

Malmkjær, K. (2004). Censorship or error: Mary Howitt and a problem in descriptive TS. In G. Hansen, K. Malmkjaer \& D. Gile (Eds.), Translation Studies: Claims, Changes and Challenges. Selected papers from the EST Congress, Copenhagen 2001 (pp. 141-155). Amsterdam: Benjamins.

McDonough Dolmaya, J. (2011a). Moral ambiguity: Some shortcomings of professional codes of ethics for translators. JoSTrans 15, 28-49. 
McDonough Dolmaya, J. (2011b). The Ethics of Crowdsourcing. Linguistica Antverpiensia 10, 97-111.

Munday, J. (Ed.). (2007). Translation as Intervention. London: Continuum.

Newmark, P. 1991. About translation. Clevedon: Multilingual Matters.

O’Sullivan, C. (2011). Croker versus Montalembert on the Political Future of England: Towards a Theory of Antipathetic Translation. In D. Asimakoulas \& M. Rogers (eds), Translation and Opposition (pp. 182-203). Bristol: Multilingual Matters.

Pym, A. (1992). Translation error analysis and the interface with language teaching. In

C. Dollerup \& A. Loddegaard (Eds.), Teaching Translation and Interpreting: Training, Talent and Experience (pp. 279-288). Amsterdam and Philadelphia: Benjamins.

Siponkoski, N. (2014). Translation under Negotiation. The Textual Interplay of Translators and Editors in Contemporary Finnish Shakespeare Translation. Vaasa: University of Vaasa. 